\title{
Evaluation of 37,438 consecutive cervical smear results in the Turkish population
}

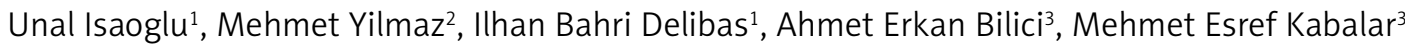

\author{
${ }^{1}$ Nenehatun Obstetrics and Gynecology Hospital, Erzurum, Turkey \\ 2Department of Obstetrics and Gynecology, Faculty of Medicine, Ataturk University, \\ Erzurum, Turkey \\ ${ }^{3}$ Department of Pathology, Education and Research Hospital, Erzurum, Turkey
}

Submitted: 18 June 2013

Accepted: 27 July 2013

Arch Med Sci 2015; 11, 2: 402-405

DOI: 10.5114/aoms.2013.38814

Copyright @ 2015 Termedia \& Banach

\section{Abstract}

Introduction: Retrospective evaluation of cervical smear results of women who attended our gynecology policlinics with various symptoms and discussion of the results in the light of the literature.

Material and methods: We performed a retrospective investigation on 37,438 Pap smear results of women who attended our hospital between January 2011 and December 2012 with a variety of symptoms.

Results: Average patient age was 43 (18-83) years. Of the Pap smear results analyzed, in 21,503 (57.4\%) findings were within normal limits, while $153(0.41 \%)$ showed epithelial cell abnormalities and 15,358 (41\%) showed inflammation. Four hundred and twenty-four (1.1\%) cases were reported to have inadequate Pap smear samples for evaluation. Of the epithelial cell abnormalities, 136 (88.8\%) were squamous cell abnormalities and 17 (11.1\%) were glandular cell abnormalities. Atypical squamous cells of unknown significance (ASCUS) were reported for 117 (0.3\%) Pap smears, while other epithelial abnormalities included atypical glandular cells of unknown significance (AGUS) in $17(0.05 \%)$ cases, low-grade squamous intraepithelial lesion (LSIL) in $8(0.02 \%)$ cases, atypical squamous cells with possible high grade lesion (ASC-H) in $8(0.02 \%)$ cases and high-grade squamous intraepithelial lesion (HSIL) in $3(0.008 \%)$ cases.

Conclusions: Public awareness should be raised on the importance of Pap smear testing repeated at appropriate intervals in the prevention and early diagnosis of cervical cancer. Health education should become more widespread, and the importance of screening programs and regular check-ups should be emphasized more often on this issue in the media.

Key words: Pap smear, screening, cervical cancer.

\section{Introduction}

Cancer is the second most common cause of death worldwide and is estimated to be the first in 2030 [1]. Cervical cancer is the second most common type of cancer among women worldwide; 50,000 new cases are reported, and 250,000 women die of cervical cancer each year [2]. According to a study that analyzed statistical data of 8 provinces in Turkey, published in 2003 by the Cancer Control Department of the Ministry of Health of the Republic of Turkey which can be seen as the closest data to represent the Turkish population, cervical cancer was the $10^{\text {th }}$ in frequency in all women's cancers and its incidence was 4.76 per hundred thou-

\author{
Corresponding author: \\ Unal Isaoglu MD \\ Nenehatun Obstetrics \\ and Gynecology Hospital \\ 25200 Erzurum, Turkey \\ Phone: +905053164680 \\ E-mail: u.isaoglu@gmail.com
}


sand. According to those figures, the incidence of cervical cancer in Turkey seems to be well below that of many countries which implement well-developed national screening programs [3].

The average age of cervical cancer patients at diagnosis is 51 , peaking at two periods of age namely, 35-59 and 60-64 [4, 5]. A healthy sex life and regular screening are very important in the prevention of cervical cancer $[1,4]$.

The Pap smear test is of extreme importance in the early detection, and, accordingly, in the prognosis of cervical cancer. This test was developed in the 1950s by the Greek scientist Georgios N. Papanicolaou, whose name was given to the method of cervical cancer screening called "Pap smear". Pap smear is a relatively inexpensive method. In the detection of cervical pathologies, conventional cytology was reported to have a sensitivity of 30$87 \%$ and specificity of $86-100 \%$, while sensitivity and specificity of the relatively new liquid-based cytology were found to be $61-95 \%$ and $78-82 \%$, respectively $[6,7]$.

In this retrospective study, we aimed to evaluate cervical smear results of women who attended our gynecology policlinics with various symptoms and discuss our results in the light of the literature.

\section{Material and methods}

We performed a retrospective investigation on 37,438 consecutive Pap smear results of women who attended our hospital between January 2011 and December 2012 with a variety of symptoms. After taking a cervical smear sample with a cytobrush, material was thinly spread on a single glass slide and fixed with a spray (AKAT spray) held at about $25 \mathrm{~cm}$ distance from the sample. Cytological evaluation of cervical smears taken from the patients was performed using the 2001 Bethesda grading system [8]. We included the first smear result of the same patient if she had taken multiple smears within 1 year.

\section{Statistical analysis}

For statistical analysis, the SPSS 15.0 (Chicago, USA) software package was used. Smear results were expressed as numbers and percentages.

\section{Results}

Average patient age was $43(18-83)$ years. Of the Pap smear results analyzed, 21,503 (57.4\%) reported findings within normal limits, while 153 (0.41\%) included epithelial cell abnormalities and $15,358(41 \%)$ included inflammation. Four hundred and twenty-four (1.1\%) cases were reported to have inadequate Pap smear samples for evaluation. Of the epithelial cell abnormalities, 136 (88.8\%) were squamous cell abnormalities and 17 (11.1\%) were glandular cell abnormalities. Atypical squamous cells of unknown significance (ASCUS) were reported for 117 (0.3\%) Pap smears, while other epithelial abnormalities included atypical glandular cells of unknown significance (AGUS) in 17 (0.05\%) cases, low-grade squamous intraepithelial lesion (LSIL) in $8(0.02 \%)$ cases, atypical squamous cells with possible high grade lesion (ASC-H) in $8(0.02 \%)$ cases and high-grade squamous intraepithelial lesion (HSIL) in $3(0.008 \%)$ cases (Table I).

\section{Discussion}

Cervical cancer is the second most common type of cancer among women worldwide; 50,000 new cases are reported, and 250,000 women die of cervical cancer each year [2]. The average age at diagnosis is 51 in cervical cancer patients, incidence peaking at two periods of age namely, 35-59 and 60-64 [4].

Initiation of sexual intercourse at an early age, multiple sexual partners, low socio-economic status, smoking, vitamin A deficiency, and human papillomavirus (HPV) infection are well-established risk factors for cervical cancer [9, 10]. In developing countries, the annual incidence of cervical cancer and cancer-related deaths are both higher than in developed countries where use of routine Pap smear screening has reduced rates of invasive cervical cancer [11, 12]. Thus, prevention and early treatment of cervical cancer are dependent on identification and elimination of variable risk factors, and implementing proper screening tests for appropriate age groups [13].

Cervical cancer screening should be initiated 3 years after the first sexual intercourse or at age 21. Pap smear screening should be performed once a year under the age of 30 , while it should be repeated at least every 2-3 years in the case of 3 consecutive negative smear results in women over the age of 30 [14-16].

Conventional cytology was reported to have a sensitivity of $30-87 \%$ and specificity of $86-100 \%$

Table I. Cervical smear results of the cases

\begin{tabular}{|lcc|}
\hline Cervical cytology & Cases $(n)$ & Ratio (\%) \\
\hline Normal & 21503 & 57.4 \\
\hline Inflammation & 15358 & 41 \\
\hline Inadequate material & 424 & 1.1 \\
\hline ASCUS & 117 & 0.3 \\
\hline AGUS & 17 & 0.05 \\
\hline LSIL & 8 & 0.02 \\
\hline ASC-H & 8 & 0.02 \\
\hline HSIL & 3 & 0.008 \\
\hline
\end{tabular}


in the detection of cervical pathologies, while sensitivity and specificity of the relatively new liquid-based cytology were found to be 61-95\% and $78-82 \%$, respectively $[5,6]$. In their study on 8100 subjects, Celik et al. aimed to compare liquid based cytology and conventional cytology, and found that although the frequency of reports denoting inadequate smear samples was reduced with the use of liquid-based cytology, there was no statistically significant difference between the two diagnostic methods in detecting atypical squamous cell and other epithelial cell abnormalities [17]. Conventional cervical cytology is the preferred method of cervical cytology evaluation in our center.

In their study evaluating 500 Pap smear samples, Talukder et al. reported that they identified inflammation in $82.8 \%$, ASCUS in $0.6 \%$, HSIL in $1.2 \%$ and squamous cell carcinoma in $0.2 \%$ of the samples [18]. Of the 6706 cervico-vaginal smears reported by Ozdamar et al., 92.1\% were benign, $0.7 \%$ were malignant, $0.8 \%$ were suspected to have a malignancy and $6.4 \%$ were inadequate to evaluate [19]. Aydın et al., in a community-based cervical smear screening performed in Antalya province, reported that, of all the samples, $90.6 \%$ were reported as benign, $0.3 \%$ as ASCUS, $0.1 \%$ as LSIL, and $0.07 \%$ as HSIL [20]. In a study including 4122 cases, Bozkurt reported chronic non-specific inflammation in $90.5 \%$, ASCUS in $4 \%$, HSIL $0.1 \%$ and squamous cell carcinoma in $0.2 \%$ of the samples [21]. In a similar study Eroğlu et al. reported chronic non-specific inflammation in $79.6 \%$, ASCUS in $0.5 \%$, LSIL in $0.02 \%$, $\mathrm{HSIL}$ in $0.02 \%$ and squamous cell carcinoma in $0.02 \%$ of the samples [22]. Nazlican et al., in their study including 150 cases, reported that $48.7 \%$ of the samples were normal while non-specific inflammation was identified in $24.0 \%$, bacterial vaginosis in $13.3 \%$, reactive changes secondary to inflammation in $12.7 \%$ and ASCUS in $1.3 \%$ [23]. In our study which included 37,438 cases, $57.4 \%$ of the samples were identified as normal while inflammation was detected in $41 \%$, ASCUS in $0.3 \%$, AGUS in $0.05 \%$, LSIL in $0.02 \%$, ASC-H in $0.02 \%$, and HSIL in $0.008 \%$ of the samples. Pap smears reported as inadequate for evaluation constituted $1.1 \%$ of all samples. Early stage cervical cancer was detected in 1 case which was reported as ASC-H and in 2 cases which were reported as HSIL in Pap smear results. Our results are similar to the above-mentioned results of Aydin et al. and Eroğlu et al. The rate of cytological diagnosis of ASCUS identified in our study was lower than those reported by Bozkurt and Nazlican et al. This fact may be due to differences among study groups for risk factors such as multiple partners and tobacco use, and number of cases included in the studies.
The Pap smear test is a cheap and easily applied screening test. Early diagnosis of cervical cancer can be made by routine Pap smear testing, and thus the incidence of cervical cancer and cancer-related death rates can be reduced.

Public awareness should be raised on the importance of Pap smear testing repeated at appropriate intervals in the prevention and early diagnosis of cervical cancer. Health education should become more widespread, and the importance of screening programs and regular check-ups should be emphasized more often on this issue in the media.

\section{Conflict of interest}

The authors declare no conflict of interest.

\section{References}

1. Aslan D. Contemporary problems in public medicine and approaches. Ankara Tabib Odası 2009; 25-45.

2. WHO/ICO (2010). Fact Sheet 2010 Available at: http:// apps.Who.Int/hpvcentre/statistics/dynamic/ico/country_pdf/tur_fs.pdf?Cfid=4107527\&cftoken $=2$ (accessed on October 2011).

3. Ozgul N. Current state of cervical cancer and cervical cancer screening in Turkey. In: Cancer control in Turkey. 1 ed. Tuncer AM (ed.). Ankara 2007; 349-58.

4. Kaya M. "Cervical cancer" with public health approach. HUKSAM Yayinlari 2009; 34-73.

5. Biedka M, Makarewicz R, Kopczyńska E, Marszałek A, Goralewska A, Kardymowicz H. Angiogenesis and lymphangiogenesis as prognostic factors after therapy in patients with cervical cancer. Contemp Oncol (Pozn) 2012; 16: 6-11.

6. Belison J, Qiao YL, Pretorius R, et al. Shanxi province cervical cancer screening study: a cross-sectional comperative trial of multiple techniques to detect cervical neoplasia. Gynecol Oncol 2001; 83: 439-44.

7. Kulasingam SL, Hughes JP, Kiviat NB. Evaluation of human papillomavirus testing in primary screening for cervical abnormalities: comparison of sensitivity, specificity, and frequency of referal. JAMA 2002; 288: 1749-57.

8. Solomon D, Davey D, Kurman R, et al. The 2001 Bethesda system terminology for reporting results of cervikal cytology. JAMA 2002; 16: 2114-9.

9. Turkistanlı EC, Sogukpinar N, Saydam BK, Aydemir G. Cervical cancer prevention and early detection - the role of nurses and midwives. Acian Pac J Cancer Prev 2003; 4: 15-21.

10. Soler ME, Gaffikin L, Blumenthal PD. Cervical cancer screening in developing countries. Prim Care Update $\mathrm{Ob}$ Gyns 2000; 7: 118-23.

11. Waxman AG. Guidelines for cervical cancer screening, history and scientific rationale. Clin Obstet Gynecol 2005; 48: 77-97.

12. Saraiya UB. Preventable but not prevented: the reality of cervical cancer. J Obstetr Gynecol Res 2003; 29: 351-9.

13. Ayhan A, Durukan T, Gunalp S, et al. Basic knowledge of obstetrics and gynecology. Gunes Medical Publishing. 2 ed. Ankara 2008; 1027.

14. American College of Obstetricians and Gynecologists. ACOG practice bulletin. Cervical Cytology screening. Number 45, August 2003. Int J Gynaecol Obstet 2003; 83: 237-47. 
15. Gokaslan H, Uyar EE. Screening cervical cancer with Pap smear. Turk Aile Hek Derg 2004; 8: 105-10.

16. Kavak ZN, Eren F, Pekin S, Kullu S. A randomized comparison of the 3 Papanicolaou smear collection methods. Aust N Z J Obstet Gynaecol 1995; 35: 446-9.

17. Celik C, Gezginc K, Toy H, Findik S, Yilmaz O. A comparison of liquid-based cytology with conventional cytology. Int J Gynecol Obstet 2008; 100: 163-6.

18. Talukder MS, Huq MH, Haque A. Evaluation of 500 cases of Pap's test in Mymesingh. Mymensingh Med J 2002; 11: 26-8.

19. Ozdamar SO, Bektas S, Barut F, et al. Cytology experience of Zonguldak Karaelmas University between 2003 and 2005. Turk Patoloji Derg 2006; 22: 92-5.

20. Aydin S, Erturk B, Karaklinic H. An example of community based cervical cancer screening. Available at: www. ukdk.org/pdf/kitap/en/48. (accessed on October, 2010).

21. Bozkurt TT. Our cervical smear screening results between 2000 and 2005 in Istanbul Education and Research Hospital. Thesis. Istanbul 2007.

22. Eroğlu C, Unlu Y, Eryilmaz MA, Gönenc O. Cervicovag inal smear screening experience early cancer diagnosis-screening and Education Center Konya Education and Research Hospital. JGON 2008; 21: 91-6.

23. Nazlican E, Akbaba M, Koyuncu H, Savas N, Karaca B. Cervical cancer screening between 35-40 aged women at Kisecik Region of Hatay Provinence. TAF Prev Med Bull 2010; 9: 471-4. 